\title{
Biopolis - przyroda i miasto
}

Elżbieta Rybicka

TEKSTY DRUGIE 2018, NR 2, S. 57-74

DOI: $10.18318 /$ td.2018.2.4

\section{Rezerwat: Miasto}

W 2013 roku krakowski Bunkier Sztuki przeobraził się w miejsce wystawy-zdarzenia Rezerwat: Miasto ${ }^{1}$ : na podłodze piętrzyły się zwalone przez wiatr drzewa, po salach biegał pies, na ekranach migotały rzeki, a między nimi Cecylia Malik z charakterystycznym dla siebie zaangażowaniem opowiadała o pracy i współpracy. Zebrane w jednym miejscu projekty artystki (m.in. 365 Drzew, Kolektyw: Modraszek, Obrazy z lasu tęgowego, 6 rzek) pokazywały przede wszystkim równoległą i niespodziewaną rzeczywistość miasta jako rezerwatu, drzew i lasów łęgowych, częściowo dzikich rzek czy łąk, siedlisk motyla modraszka. Co więcej, wystawa nie tylko gromadziła dokumentację projektów, ale również angażowała odwiedzających w kolejny, w części przestrzeni zorganizowano bowiem sztab akcji Warkocze Białki, której celem był protest przeciw regulacji górskiej rzeki. Akcje prezentowane na wystawie to jednak nie tylko aktywizm artystyczny związany z miejską przyrodą, ale też próba podwójnego

1 Kuratorką wystawy była Aneta Rostkowska.

\section{Elżbieta Rybicka}

- pracuje w Katedrze Antropologii Literatury i Badań Kulturowych (UJ). Autorka książek Formy labiryntu w prozie polskiej XX wieku (2000), Modernizowanie miasta. Zarys problematyki urbanistycznej wnowoczesnej literaturze polskiej (2003) oraz Geopoetyka. Przestrzeń i miejsce we współczesnych teoriach i praktykach literackich (2014, Nagroda PAN im. A. Brücknera). Zajmuje się zwrotem przestrzennym, geopoetyką, antropologią miejsca i kulturą miasta. Kontakt: elzbieta. rybicka@uj.edu.pl 
poszerzenia - z jednej strony pola sztuki, a z drugiej miejskiej wspólnoty jako kolektywu złożonego zarówno z naukowych ekspertów od przyrody, rodziny, przyjaciół, mieszkańców miasta, jak i podmiotów nie-ludzkich: motyla modraszka, psa husky, drzew czy bobrów:

Wystawa w Bunkrze Sztuki to opowieść o miejskim rezerwacie, w którym natura nieustannie splata się z tym, co ludzkie - jerzyki wiją gniazda na dachach bloków, ludzie przebierają się za motyle w obronie prawa do zieleni, obrazy „wyrastają" z drzew, a bobry rzeźbią z drewna wiewiórkę. ${ }^{2}$

W 2016 roku we Wrocławiu zrujnowany, poniemiecki budynek stacji transformatorowej nad Oławą stał się miejscem osobliwego eksperymentu - początkiem współpracy Joanny Rajkowskiej i naturalnego ekosystemu. Trafostacja niszczała od lat, jak w wielu innych przypadkach została już zasiedlona przez roślinność ruderalną, artystka po konsultacjach z botanikami dosadziła jeszcze kilka innych gatunków cieniolubnych: paprocie, bluszcze, bodziszki, mchy, trzmieliny, i doprowadziła stałe zasilanie wodą. Dzięki niej naturalna sukcesja roślinna uzyskała dodatkowe wsparcie i możliwość aktywnego i, co istotne, pozbawionego ludzkiej kontroli działania. Architektura trafostacji stała się konstrukcyjnym szkieletem dla żywej roślinnej „rzeźby”, którą Rajkowska nazywa „maszyną obiegu materii”" , włączając ją tym samym w szczególny rodzaj metabolizmu miejskiego. I choć Trafostacja wyrasta na ruinach, to jednak nie prowadzi do melancholijnej w gruncie rzeczy konstatacji schyłku, zniszczenia czy zaniku, lecz uzmysławia continuum życia materii, gdy erozja i rozkład kooperują z regeneracją. Uświadamia zarazem, że w tym obiegu materii to nie człowiek (i artysta) będzie siłą sprawczą.

W tym samym roku we Wrocławiu został zrealizowany także inny projekt odkrywający powiązania ludzko-roślinne - Grün/Zielone Karoliny Grzywnowicz. Artystka zebrała opowieści mieszkańców Wrocławia o ich prywatnych pomnikach pamięci - drzewach, ważnych w perspektywie biografii osobistych i rodzinnych. $Z$ tych relacji o brzozach, czereśniach, platanach, morwach czy magnoliach wyłonił się szczególny rodzaj biopamięci, splatającej ludzkie wspomnienia i emocje, niemiecko-polską historię miasta oraz drzewa, które

2 Cecylia Malik. Rezerwat Miasto, red. M. Niedośpiał. A. Rostkowska, Galeria Sztuki Współczesnej Bunkier Sztuki i Towarzystwo na Rzecz Ochrony Przyrody, Kraków 2013, S. 16.

3 Zob. Obieg materii. Od-swajanie. Rozmowa Oli Jach z Joanną Rajkowską: http://www.rajkowska. $\mathrm{com} / \mathrm{pl} /$ teksty/348 (20.02.2017) 
ustanawiają jej ciągłość mimo powojennego cięcia. Wydaje się, że najtrafniej te powiązania opisać można za pomocą roślinnej metafory „zroślaków”, pojawiającej się w narracji Aliny Drapelli-Hermansdorfer": zroślaki to zrośnięte ze sobą różne gatunki drzew, a sama technika takich nasadzeń była bardzo popularna na Dolnym Śląsku od końca XVIII wieku, w okresie powojennym zniknęła i dopiero teraz została reaktywowana.

Akcje Cecylii Malik, Joanny Rajkowskiej i Karoliny Grzywnowicz to oczywiście zaledwie trzy przykłady z szerokiego pola praktyk artystycznych, w którym mieszczą się tak zróżnicowane działania, jak między innymi Architektura arborealna Magdaleny Abakanowicz, Dzieła legną się w szczelinach rzeczywistości Teresy Murak, Wieże tlenowe i Natura (do) mieszkania Jarosława Kozakiewicza, Mój ogród Julity Wójcik, Raj Pawła Althamera, Widok na Czechówkę Ludomira Franczaka czy wcześniejsze prace Time Landscape Alana Sonfista, 7000 dębów Josepha Boyeusa lub Wheatfield Agnes Denes. Można wprawdzie spojrzeć na nie z punktu widzenia land artu, sztuki ekologicznej czy sztuki zrównoważonego rozwoju (sustainable art), wymagają one jednak, jak sądzę, wprowadzenia innych ram pojęciowych i wyjaśniających, ponieważ wszystkie odnoszą się do środowiska miejskiego. Z tego powodu chciałam uczynić je punktem wyjścia dla szerszego problemu: zrekonstruowania historii relacji przyrody i miasta, a pytanie o przyrodę w mieście będzie zarazem pytaniem o miejską wspólnotę, o historyczne warunki poszerzania tej wspólnoty rozumianej jako dynamiczny, ciągle ewoluujący projekt. Z tej konfrontacji - współczesnej sztuki i „zielonej” urbanistyki, chciałabym wyprowadzić (szkicowo i hipotetycznie) zarys biopolis ${ }^{5}$ jako koncepcji postulatywnej, która splata materialne, społeczne i polityczne życie miasta ze środowiskiem przyrodniczym.

\section{Zazielenianie nowoczesności}

W urbanistyce ostatnich kilkunastu lat pojawiła się wyraźna tendencja do przekształcania miejsc i obszarów industrialnych w tereny zielone. Światowymi ikonami tego procesu są Promenade Plantée w Paryżu i High Line w Nowym Jorku, parki urządzone na dawnych estakadach kolejowych, czy przemiana zakorkowanej trasy szybkiego ruchu w Seulu dzięki odsłonięciu

4 Zob. http://grun.wrocenter.pl/zroslaki/ (20.02.2017)

5 O innych filozoficznych aspektach biopolis pisze Piotr Juskowiak Kto ma prawo do biopolis? Agamben, Negri i spór o metropolię, "Praktyka Teoretyczna” 2011 nr 2/3. 
schowanej pod nią przed laty rzeki i stworzenie wzdłuż jej brzegów parku Cheonggyecheon. Innym jeszcze przypadkiem jest rozkwitające miejskie rolnictwo w zbankrutowanym, postindustrialnym Detroit, w którym w opuszczonych parkach i na trawnikach powstało ponad tysiąc miejskich farm i ogródków.

Logika tych działań wydaje się przewidywalna - po fazie intensywnej industrializacji przychodzi krytyczna reakcja i korekta błędów. Niemniej logika ta, bez wątpienia słuszna, zakłada jednak jednoliniowość i jednowartościowość historii nowoczesnej urbanistyki i planowania miejskiego. Historii ukierunkowanej na ujarzmianie przyrody, regulowanie i zakopywanie rzek, przekształcanie terenów zielonych i rolniczych w przemysłowe. Historii, innymi słowy, sztuczności i miejskiej kultury rozumianej jako eliminacja przyrody. Miejska nowoczesność rozpoczyna się wszakże od pochwały sztuczności w Malarzu życia nowoczesnego Charles'a Baudelaire'a, a jej krytyczna teoria i diagnoza od melancholijnej i niezwykle sugestywnej w swej sile i skali oddziaływania refleksji Waltera Benjamina, ufundowanej na kulturze materialnej XIX-wiecznego Paryża. A w Pasażach, które wyznaczyły i ciągle wyznaczają kierunki myślenia o nowoczesności, przyroda niemal się nie pojawia.

O wyjątkowej ekspansywności i trwałości takiej wykładni może świadczyć fakt, że jeszcze w latach 9o. Rem Koolhaas w Delirycznym Nowym Jorku pisze o Metropolii, która zastąpiła Naturę, a Central Park nazywa sztucznym i „syntetycznym Dywanem Arkadyjskim”. I przy tej metaforze parku jako sztucznego Dywanu Arkadyjskiego warto się zatrzymać, ponieważ trafia ona w sedno kłopotliwego i w moim przekonaniu powierzchownego rozpoznania sytuacji. Problem polega bowiem na tym, że Koolhaas prześlizguje się, $\mathrm{i}$ to dosłownie, nad parkiem, gdyż bierze pod uwagę tylko plan z 1870 roku narzucony na manhattańską Siatkę. A z tej - planistycznej - perspektywy każdy park będzie wyglądał jak ozdobny, zielony i dekoracyjny dywan. Innymi słowy, metafora parku jako sztucznego dywanu eksponuje powierzchnię, płaskość, wymiar estetyczny, choć zarazem przewrotnie przypomina sytuację, w której zamiata się pod dywan śmieci, a więc ukrywa wszelkie komplikacje i trudności, które ową estetyczną, arkadyjską dekoracyjność mogłyby zabrudzić. Historia miejskiej zieleni była zdominowana przez takie postrzeganie - estetyzujące i maskujące niepożądane brudy.

Alternatywną linię zielonej, miejskiej nowoczesności można jednak wyprowadzić z powieści opublikowanej w 1926 roku, Wieśniaka paryskiego Louisa

6 R. Koolhaas Deliryczny Nowy Jork, przeł. D. Żukowski, Karakter, Kraków 2013, s. 29. 
Aragona, która $n b$. była jedną z najbardziej emocjonujących lektur Waltera Benjamina. Rozpoczyna się ona wprawdzie od kanonicznej przestrzeni nowoczesności - paryskich pasaży w ich fazie schyłkowej w latach 20., ale zmierza następnie w inne rejony miasta, przedostatni rozdział powieści to Poczucie natury w Buttes-Chaumont i nocny spacer po parku stworzonym z inicjatywy Georges'a Haussmanna. To w tym rozdziale pojawia się park jako „nieświadome metropolii":

Tak więc dojeżdżamy do parku, gdzie gnieździ się nieświadome metropolii, wielkie czynniki miejskiego życia przybierają kształt groźby i wynurzają się nad nieokreślonymi terenami, z ich budami gałganiarzy i hodowców warzyw, w swoim konwencjonalnym majestacie i zastygłym geście posąów.?

Dla surrealistów nieświadome miało przede wszystkim potencjał anarchizujący, a nocny park Aragona to nie Arkadia, lecz awanturnicza przestrzeń poza prawem, sfera pragnień i lęków, „szaleńczy obszar, zrodzony pod czołem architekta z konfliktu Jana Jakuba Rousseau z ekonomicznymi warunkami paryskiego bytu"8. Park jako nieświadome metropolii może zatem wprowadzać wszelkie niejasne siły dezorganizujące racjonalne i normatywne reżimy porządkowania.

Wychodząc od tych dwu metafor, chciałabym przejść od jednoliniowej narracji o destrukcyjnej roli urbanizacji do zróżnicowanej mapy nowoczesnej miejskości, a przede wszystkim wydobyć te koncepcje i działania, w których przyroda nie była „zewnętrzem" miasta, ale jego integralnym miastotwórczym czynnikiem. Wynika to z przekonania, że podobnie jak nie pamiętamy czy nie wiemy o rzekach zakopanych, choć często dalej płynących podziemnymi kanałami, tak przeoczyliśmy naturalną historię miast. Można wytłumaczyć to częściowo faktem, że historia miejskiej przyrody została ograniczona do historii parków i ogrodów, ta natomiast była pisana z perspektywy zmieniających się stylów ogrodowo-parkowych, a więc z punktu widzenia estetyki.

W proponowanej archeologii alternatywnej „zielonej” nowoczesności ważne będzie dla mnie ujęcie relacyjne, zatem nie tyle zieleń miejska sama w sobie (gdyż ta jest zazwyczaj przedmiotem zainteresowania architektów

7 L. Aragon Wieśniak paryski, przeł. A. Międzyrzecki, PIW, Warszawa 2015, S. 152.

8 Tamże, s. 149-150. 
krajobrazu), ile jej społeczne i kulturowe powiązania. Można bowiem spojrzeć na nią przez pryzmat dziejów konfliktów, regulacji dostępu, segregacji czy demokratyzacji, uwzględnić więc nie tyle jej estetykę, ile społeczne, ekonomiczne i polityczne uwarunkowania. A w takim ujęciu byłyby to dzieje w gruncie rzeczy dystrybucji praw do miejskiej zieleni, dzieje odgradzania lub otwierania. Historia nie tyle utopii arkadyjskich i niedzielnych spacerów, ile kolejnych rebelii lub interwencji - od robotniczych ataków na ogrodzenia prywatnych ogrodów w Londynie i demonstracje w Hyde Parku po współczesny guerilla gardening, interwencję w ramach pierwszej edycji festiwalu Art Boom Co jest za murem?, upominającą się o prawa mieszkańców do zamkniętych krakowskich ogrodów klasztornych, czy wreszcie olbrzymie, wielotysięczne protesty w obronie parku Gezi w Stambule w 2013 roku. Ten ostatni przykład zresztą znakomicie dowodzi, z jak złożonymi i historycznie głębokimi procesami mamy do czynienia - walka o zachowanie parku to nie tylko konflikt między ekologami i deweloperami, ale jak zauważa Deyan Sudjic, batalia o tożsamość Stambułu i Turcji ${ }^{9}$. Park Gezi został bowiem założony w latach 30. XX wieku z inicjatywy Atatürka, na miejscu dawnych osmańskich koszar wojskowych, by wzmocnić świecki i nowoczesny charakter miasta. Był więc aktem wieloskalowej modernizacji, odrzucanej przez obecne władze ${ }^{10}$.

Kanoniczna wersja historii nowoczesnej urbanistyki rozpoczyna się od przebudowy Paryża w latach 1852-1869 prowadzonej przez Georges'a Haussmanna. W dominującej krytycznej wykładni" uwaga skoncentrowana jest na idei przeciwdziałania rewolucjom za pomocą budowy bulwarów na tyle szerokich, by uniemożliwiły one stawianie barykad. Warto jednak przypomnieć, że to jeden z aspektów modernizacji, ponieważ celem Haussmanna była również walka z epidemiami cholery, w latach 1832-1835 oraz 1848-1849 z jej powodu zmarło prawie 40 tysięcy osób, a wysoka śmiertelność wynikała między innymi z faktu, że Sekwana była jednocześnie źródłem wody pitnej i zlewiskiem nieczystości.

Za sprawą Haussmanna i jego współpracowników Jean-Charles'a Alphanda oraz Jean-Pierre’a Barillet-Deschamps'a znacząco zwiększyły się tereny

D. Sudjic /ęzyk miast, przeł. A. Sak, Karakter, Kraków 2017, s. 65.

Tamże, s. 65-68. 
zieleni w Paryżu, co było tym bardziej wskazane, że większość drzew paryskich została wycięta właśnie na barykady. Koncepcja terenów zielonych zmierzała w stronę stworzenia systemu zieleni miejskiej, łączącego parki, skwery i zadrzewione aleje, by zagwarantować wszystkim mieszkańcom, niezależnie od statusu społecznego i ekonomicznego, możliwość dostępu do przyrody w bliskiej odległości od miejsca zamieszkania ${ }^{12}$. To wówczas powstały Lasek Buloński, Las Vincennes, parki Montsouris i Monceau oraz, może najciekawszy, park Buttes-Chaumont założony, jak we współczesnych rewitalizacjach poprzemysłowych, na terenie wysypiska śmieci, w dawnym kamieniołomie.

Efektem wdrożenia systemu parkowego stworzonego w ramach haussmanizacji miało być stworzenie dostępu do zieleni dla wszystkich, choć nie dla wszystkich w tym samym miejscu. Paryski Lasek Buloński przeznaczony był bowiem dla elit społecznych, natomiast Las Vincennes - dla robotników ${ }^{13}$. Strategia izolacji i dystrybucji dostępu do zieleni była oczywiście ekwiwalentem hierarchii i podziałów społecznych, które wyraźnie naznaczają specyfikę XIX-wiecznych założeń parkowych. Ten segregacyjny wymiar parków publicznych utrzymywał się długo ${ }^{14}$. Jeszcze pod koniec XIX wieku w rozporządzeniach Magistratu krakowskiego pojawiały się socjoekonomiczne regulacje, hierarchizujące dostęp do ławek na Plantach:

Nadto służba plantacyjna obowiązana jest nie dopuszczać na plantacyach żebraniny, jak również, aby pijacy i ludzie źle odziani rozpierali się lub rozkładali po ławkach, tudzież iżby w godzinach popołudniowych, gdy porządniejsza publiczność używa przechadzki, ławki przy głównych drogach były zajmowane przez służące lub gawiedź. ${ }^{15}$

A w ważnej publikacji z 1910 roku Zadrzewienie miast naszych autorstwa Edmunda Jankowskiego, botanika i ogrodnika, członka warszawskiego

12 P. Baster Parki francuskich projektantów - współrealizatorów idei Haussmanna, "Architektura. Czasopismo Techniczne" 2010 nr 5-A.

13 Ch. Prendergast Paris and the Nineteenth Century, Blackwell, Oxford-Cambridge 1992, s. 170-172.

14 Segregacja rasowa w parkach Stanów Zjednoczonych, zwłaszcza na południu, trwała do lat 50. XX wieku - zob. J. Byrne, J. Wolch Nature, Race, and Parks: Past Research and Future Directions for Geographic Research, "Progress in Human Geography” 2009 No. 6.

15 Obwieszczenie Magistratu z 16 kwietnia 1896 roku, w: Archiwum Narodowe w Krakowie. Zbiór afiszy i plakatów (sygn. 224). 
Komitetu Plantacyjnego, mocno manifestują się warunki dostępności do zieleni uzależnione od stopnia cywilizacyjnej ogłady:

W tym miejscu jeszcze wypadnie zastanowić się nad pytaniem: kogo do ogrodu miejskiego wpuszczać należy? Najchętniej odpowiedzielibyśmy: „wszystkich”. Niestety, próby zrobione w Warszawie przekonały, że tego u nas jeszcze zrobić niepodobna, bo wtedy zalegają ogród różne włóczęgi i próżniaki, ludzie nie tyle może z gruntu zepsuci, ile zupełnie ciemni, którzy szkoły wcale nie widzieli, lub byli w złej albo zbyt krótko. [...] Zatem, dopóki się tego stanu nie zmieni i nie poprawi przez oświatę, na co trzeba jeszcze dużo czasu i pracy, ogród dla takich żywiołów musi być zamknięty. Pozostaną dla nich zewnętrzne ławki przy zieleńcach i parki ludowe. ${ }^{16}$

Parki mogą więc legitymizować porządek społeczny przez regulację dostępu i segregację, ale mogą też porządek społeczny, przynajmniej intencjonalnie, transformować. I to jest przypadek Central Parku w Nowym Jorku. W deklaracjach jego twórcy Fredericka Law Olmsteda park miał być przede wszystkim narzędziem demokratyzacji, otwartą dla wszystkich strefą kontaktu dla bogatych i biednych. Miał poszerzać miejską wspólnotę, a zarazem przeciwdziałać społecznym skutkom urbanizacji, wychowywać i edukować. By dostrzec te korekcyjne, ale i demokratyczne funkcje, istotny będzie kontekst historyczny - Nowy Jork w latach 50. XIX wieku był sceną wielkiego kryzysu, jak skrupulatnie relacjonuje Howard Zinn, w 1849 roku w zamieszkach zginęło lub zostało rannych ponad 200 robotników, po załamaniu gospodarczym w 1857 roku liczba bezrobotnych sięgała już 200 tysięcy, na ulicach wielokrotnie dochodziło do zamieszek, a w listopadzie tłum zajął ratusz ${ }^{17}$.

W tych okolicznościach terapia społeczna za pomocą parku mogła wydawać się jego twórcom rozwiązaniem rozładowującym napięcia, służącym osłabieniu niebezpiecznych inklinacji klas miasta pozbawionych praw ${ }^{\mathbf{1 8}}$. Park jednak nie tylko demokratyzował, ale normatywnie (dzięki regulaminom

16 E. Jankowski Zadrzewienie miast naszych, w: Ogród polski wXIX wieku: antologia tekstów, Ośrodek Ochrony Zabytkowego Krajobrazu, Warszawa 1998, s. 89.

H. Zinn Ludowa historia Stanów Zjednoczonych. Od roku 1492 do dziś, przeł. A. Wojtasik, Wydawnictwo Krytyki Politycznej, Warszawa 2016, s. 300-301. 
i parkowym strażnikom) cywilizował, a w zasadzie dyscyplinował, w nadziei, że uda się wychować klasy niższe ${ }^{19}$. Trudno powiedzieć, by ten pedagogiczny eksperyment społeczny się powiódł, w latach 8o. lud coraz częściej anarchizował normatywny porządek, mimo zakazów odbywały się w nim demonstracje, w stronę karet rzucano kamienie, a na łąkach wypasano kozy.

I choć Olmsted był utopijnym demokratą, a Central Park chyba najważniejszym przykładem projektowania zieleni miejskiej jako czynnika sprawczego procesów demokratyzacyjnych, to jednak właśnie ten park najlepiej dowodzi nierozwiązywalnych sprzeczności XIX wieku. Wprawdzie miał rozładowywać konflikty społeczne, a mimo wszystko stał się po raz kolejny ich sceną. Do tego dochodzi jeszcze dopiero od niedawna odkrywana czarna historia parku, przed budową wywłaszczono bowiem lokalną afroamerykańską wspólnotę, która miała na tych terenach swoją osadę Seneca Village.

Istniała jednak, przynajmniej w Europie, alternatywa, jeśli lud nie chciał być cywilizowany parkiem, to być może lepszym rozwiązaniem w ówczesnych warunkach socjoekonomicznych był inny rodzaj zieleni miejskiej - ogródki robotnicze. Miejskie działki na potrzeby rolnicze pojawiły się jako integralny element urbanistyczny w Żyrardowie, jednym z pierwszych miast przemysłowych, w nowo zakładanych patronackich osiedlach robotniczych na Śląsku, a od przełomu wieku XIX i XX już w całej Polsce ${ }^{20}$. W 1909 roku powołano w Warszawie Towarzystwo Ogrodów Robotniczych, instytucję dobroczynną, która zajmowała się organizacją działek dzierżawionych przez robotników ${ }^{21}$. One również traktowane były jak lekarstwo na choroby cywilizacyjne i niepokoje społeczne, jak pisał książę Adam Woroniecki w 1905 roku:

Gdyby ogród robotniczy był środkiem aptecznym, lekarze nie zapisywaliby nic innego przeciw alkoholizmowi i tuberkulozie [...]. Współczesna imigracja ludności wiejskiej do miast, odrywając ludzi od ziemi, jest bez wątpienia jedną z przyczyn i tej nędzy, jaka w miastach panuje, i tego radykalizmu społecznego, jaki się coraz bardziej wśród ludności robotniczej szerzy. Ruchu tego powstrzymać nie sposób, ale strasznym skutkom jego

Tamże, s. 166.

Zob. M. Zych Kilka arów, cały świat. O poznawaniu ogródków działkowych, w: Dzieło-działka, red. M. Szczurek, M. Zych, Muzeum Etnograficzne im. Seweryna Udzieli w Krakowie, Kraków 2012, S. 21-30. wanych w Królestwie Polskim, "Architektura. Czasopismo Techniczne” 2012 nr 8A, s. 173. 
można po części zaradzić, chcąc mieć partię zachowawczą, trzeba przede wszystkim dać ludziom coś do zachowania. ${ }^{22}$

Oprócz zatem podstawowej funkcji dostarczania żywności, ogródki działkowe spełniały też role prewencyjne, gdyż ich uprawianie miało zapobiegać rewolucji. I choć ogródki robotnicze funkcjonowały na marginesie, to właśnie one chyba dobitniej dowodzą upłynnienia rozumienia relacji między miastem i przyrodą w kategoriach opozycji. Obecnie dostrzega się w ruchu działkowym inicjatywę pionierską wobec współczesnego miejskiego ogrodnictwa ${ }^{23}$, a przy tej okazji ogródki poddawane są antropologicznej reinterpretacji. Magdalena Zych zwraca na przykład uwagę, że wychodzą one poza wizualną konsumpcję przyrody i estetykę malowniczości, by prowadzić w stronę cielesnego praktykowania, całościowego doświadczenia życia i „wspólnoty żywych organizmów: ludzi, roślin, zwierząt"24.

W tej epizodycznej rekonstrukcji historii zielonej nowoczesności chciałabym podkreślić kilka szczegółów - po pierwsze, momentem przejścia z przednowoczesnej, często średniowiecznej struktury przestrzennej miast było wyburzenie obronnych murów i powstanie w ich miejsce parków (krakowskie Planty, wiedeński Ring, wrocławski Park Miejski i Park Ludowy). Rozwój miast przemysłowych był również skorelowany z zakładaniem parków, w samym Manchesterze w XIX wieku założono trzy parki, w Londynie udział terenów zielonych zwiększył się z 500 do 1500 hektarów ${ }^{25}$. Jakkolwiek brzmi to jak paradoks, nietrudno zauważyć, że w miastach nowoczesnych, w tym także przemysłowych, nieustannie wypracowywano mechanizmy samoobrony, zielony bufor bezpieczeństwa, chroniący przed skutkami urbanizacji. Miejska przyroda w związku z tym pełniła funkcję terapeutyczną, zarówno jeżeli chodzi o kwestie „chorób” industrialnych (zanieczyszczenia), jak i społecznych, będąc narzędziem rozwiązywania lub łagodzenia konfliktów socjoekonomicznych. Sama metaforyka wówczas stosowana, zwłaszcza parku jako „zielonych płuc”,

22 A. Woroniecki Ogrody robotnicze. Odczyty popularne dla Towarzystw Polskich, w: Ogród polski wXIX wieku..., s. 86.

23 P. Cetnarski i in. Proste historie. 200 lat ogrodów działkowych w polskich miastach. Zapomniany i niedoceniany element miejskiego ogrodnictwa, w: Architektura niezrównoważona, Fundacja Bęc Zmiana, Warszawa 2016.

25 A. Zachariasz Zieleń jako współczesny czynnik miastotwórczy ze szczególnym uwzględnieniem roli parków publicznych, Wydawnictwo Politechniki Krakowskiej, Kraków 2006, s. 30-42. 
wyraźnie dowodzi, że przyroda traktowana była nie jako coś zewnętrznego, ale jako wewnętrzny organ miasta, umożliwiający miejski metabolizm.

Stały za tym regulacje prawne, a dobrym przykładem, choć nieco późniejszym, jest polskie ustawodawstwo, Minister Spraw Wewnętrznych Felicjan Sławoj-Składkowski w okólniku o zadrzewieniu z 1927 roku zarządzał:

Polecam w ciągu miesiąca marca i kwietnia 1928 r. dokonać zadrzewień placów i ulic miast, miasteczek i wsi. Zadrzewianie ma być przeprowadzone przez fachowców, o ile możliwe drzewami rozwiniętymi. Posadzone drzewa mają otrzymać dostateczną ochronę przed ich uszkodzeniem. [...] Żądam, by akcja powyższa nie była traktowana jako skutek wymuszonego zarządzenia, lecz jako świadome dążenie do zmiany wyglądu i polepszenia jakości powietrza miast i wsi. Pożądanem byłoby stworzenie obecnie w każdej miejscowości Komisji Zadrzewień. ${ }^{26}$

Również dokumenty o charakterze międzynarodowym, to znaczy Karta Ateńska z 1933 roku, zawierająca wytyczne dla projektowania urbanistycznego, wyraźnie zaznaczały konieczność uwzględnienia terenów zielonych w planowaniu przestrzennym.

Każda koncepcja miejskiej zieleni, czy w postaci parków, czy w postaci ogródków działkowych, zakłada wizję tego, czym ma być przyroda w mieście, jaką rolę ma odgrywać wobec mieszkańców, ustanawia więc zmienne formy relacji między miastem, jego mieszkańcami i środowiskiem przyrodniczym. Regulacje dostępu i prawa do zieleni miejskiej są natomiast wykładnikiem stosunków społecznych, dlatego wyjście z feudalnego systemu stanowego i stopniowe zmiany struktury społecznej są wyjątkowo mocno skorelowane z historią parków. W ciągu XIX wieku przeszły one od fazy zamkniętej (ogrody przy rezydencjach królewskich) przez stopniowe i częściowe ich otwieranie do fazy ogrodów publicznych i ludowych. Historia parków dowodzi przy tym, że segregacja społeczna i demokratyzacja były procesami dynamicznymi, ciągle ewoluującymi w stronę poszerzania dostępności. Dobitnym przykładem powiązania między przyrodą i społecznością jest chyba najważniejsza urbanistyczna utopia - koncepcja miast-ogrodów Ebenezera Howarda, która była ufundowana przede wszystkim na reformie społecznej. 
Czy kwestia prawa do zieleni miejskiej została rozwiązana? Otóż problem ten podlega obecnie konwersji ze społecznej na ekonomiczną i rozgrywa się między własnością publiczną a prywatną. W Polsce, poza Krakowem, był mało dostrzegalny, choć przy okazji ostatniej rzezi drzew okazało się, że nawet parki formalnie publiczne i będące własnością miasta mogą częściowo - po reprywatyzacji fragmentów, jak w Ogrodzie Saskim czy w Parku Świętokrzyskim - zależeć od prywatnych interesów. W Stanach sprywatyzowane, a niegdyś publiczne tereny zielone, jak Bryant Park, stają się po raz kolejny przyczyną konfliktu kulturowego między dominującą białą klasą średnią a mniejszościami etnicznymi i bezdomnymi. Amerykańska socjolożka Sharon Zukin nazywa ten typ wojny kulturowej pacyfikacją przez cappuccino" a jej konsekwencją jest przejęcie kontroli nad przestrzenią publiczną przez grupy ekonomicznie uprzywilejowane, w sytuacji, gdy cena kawy staje się równie silną barierą wstępu, jak dawne ogrodzenia i bilety. I tu ujawnia się chyba najbardziej znacząca aktualnie tendencja - przekształcania miejskiej zieleni w kapitał naturalny i jej utowarowienie, czego dobitnym skutkiem jest wzrost ceny działek i mieszkań w okolicach parków i ogrodów oraz gentryfikacja sąsiadujących z nimi dzielnic ${ }^{28}$. Problem prawa do zieleni miejskiej obecnie bywa więc rozpatrywany najczęściej w kategoriach sprawiedliwości środowiskowej (environmental justice) ${ }^{29}$.

\section{Prawo do dzikości}

Kwestię prawa mieszkańców do zieleni można jednak odwrócić i zapytać o prawa zieleni do życia w mieście. Jedną z nowych tendencji w stosunku do miejskiej przyrody jest bowiem uznanie jej prawa do tzw. sukcesji ekologicznej i spontanicznej kolonizacji, a wraz z nią pojawienie się koncepcji „czwartej natury", czyli natury rozwijającej się na terenach uprzednio przekształconych przez człowieka ${ }^{30}$. Prowadzi ona w stronę oddawania urbanistycznych

S. Zukin Whose Culture, Whose City? w: The City Reader, ed. by R.T. Le Gates, F. Stout, Routledge, London-New York 2000.

28 Ten typ gentryfikacji nazwany już został ekologiczną lub zieloną gentryfikacją.

29 J.R. Wolch, J. Byrne, J.P. Newell Urban green space, public health, and environmental justice: the challenge of making cities "just green enough", "Landscape and Urban Planning" 2014 No. 125, S. 234-244.

30 I. Kowarik Cities and Wilderness. A New Perspective, "International Journal of Wilderness" 2013 No. 3 . 
nieużytków, miejsc zazwyczaj intensywnie zdegradowanych, naturalnej i niekontrolowanej sukcesji roślinnej zgodnie z założeniami zielonego recyklingu. W nowych parkach nie eliminuje się zatem stref przyrodniczej dzikości, ale udostępnia ją użytkownikom ${ }^{31}$, albo wykorzystuje samorzutnie wyrastającą roślinność jako inspirację dla założenia parkowego (to między innymi przypadek High Line w Nowym Jorku, dla którego wzorem był biotop kolejowy). Jeszcze innym rozwiązaniem są pojawiające się coraz częściej w miastach (m.in. w Krakowie) łąki kwietne jako alternatywy nie tylko dla miejskich koszonych trawników, ale i monokulturowych łąk rolniczych. Paradoksalnie bowiem to miejskie łąki kwietne, sprzyjając bioróżnorodności, stają się ostoją dzikiego życia w przeciwieństwie do terenów rolnych ${ }^{32}$.

Naturalizacja miasta przebiega zresztą na wielu polach - zarówno naukowym (powstają wreszcie naturalne historie miast), infrastrukturalnym (renaturyzacja rzek, korytarze migracji zwierząt), kulturowym czy społecznym (ruchy miejskiego ogrodnictwa, rolnictwa, pszczelarstwa), ale też poza kontrolą i intencjonalnymi działaniami człowieka. Kapitalnym przykładem tego procesu jest ekosystem Pałacu Kultury i Nauki w Warszawie. W 1996 roku botaniczka Halina Galera przeprowadziła badania jego flory i okazało się, że na Pałacu rośnie 117 gatunków roślin ${ }^{33}$ - samosiejek, w tym niespotykany od XIX wieku w Warszawie gatunek paproci, zanokcica murowa, ale też pomidory, śliwy i jabłonie, brzozy, topole, klony, wierzby. Są one efektem z jednej strony naturalnych procesów miejskich, przenoszenia nasion przez ptaki i wiatr, a z drugiej ludzkiego działania, niektóre z gatunków drzew wyrosły z pestek i nasion owoców wyrzucanych na tarasy. Pałac znany jest też z innej przyrodniczej osobliwości - swoje gniazdo mają tam sokoły wędrowne, gatunek, który wyginął w Polsce, ale został w latach 9o. introdukowany. Wypuszczane w Warszawie sokoły zamieszkały w gnieździe pod iglicą, opiekują się nimi sokolnicy ze Stowarzyszenia na rzecz Dzikich Zwierząt, a do ubiegłego roku można je było podglądać dzięki kamerze.

31 K. Jakubowski „Piękno nieoczywiste”. Rola miejskich nieużytków w kształtowaniu nowej kategorii parków miejskich, "Przestrzeń i Forma” 2015 nr 2; K. Bernacki Idea parku miejskiego po 1982 roku, Wrocław 2009, s. 93-96, http://www.krajobraz.wroc.pl/galerie/2014/06/KB1.Idea_parku-_miejskiego_po_1982_roku.pdf (16.02.2017). Zob. Łąki do zadań specjalnych. Rozmowa ze Sławomirem Sendzielskim, "Magazyn Miasta" http://magazynmiasta.pl/2016/o2/20/sendzielski-laki-do-zadan-specjalnych/- (24.08.2017)

33 H. Galera, B. Sudnik-Wójcikowska Szczególnie interesujqce grupy roślin we florze Pałacu Kultury i Nauki, „Fragmenta Floristica et Geobotanica Polonica” 2000 t. 7, s. 117-128. 
Przypadek Pałacu stanowi pierwszorzędny dowód działania tak zwanej subnatury, a więc natury niekontrolowanej i najczęściej spychanej w urbanistyczną nieświadomośśc ${ }^{34}$. Miejska subnatura to nie Corbusierowskie słońce, powietrze, zieleń, ale wszelkie, jak zauważa David Gissen ${ }^{35}$, zjawiska niechciane, takie jak kurz, kałuże, brudy, robactwo, dym, spaliny, chwasty. Najczęściej niezauważane stopniowo ujawniają swoje ukryte życie, z rzadka jednak stają się przedmiotem uwagi w sztuce. Choć warto wspomnieć przynajmniej o jednej propozycji - subnatura stała się bohaterem ironicznego i futurystycznego filmu Jarosława Kozakiewicza Natura (do) mieszkania. Rekonstruuje on w konwencji mockumentary historię Osiedla za Żelazną Bramą, by w końcowych scenach pokazać grzyby i rośliny w roli aktantów, transformujących bloki w zielone działki:

Daleko idące zmiany temperatury i wilgotności powietrza spowodowały przemiany zachodzące w strukturze ścian budynków. Okazało się, że organizmy zamieszkujące od dziesiątków lat w mikroszczelinach ścian bloków poważnie przekształciły strukturę ścian w ten sposób przystosowując ją do nowych warunków klimatycznych.

Cladosporium i Stachybotrys lokalizują się najczęściej w materiałach z wysoką zawartością celulozy i o niskim poziomie azotu - może to być płyta pilśniowa albo ściany gipsowe, papier, płótno, drewno czy kurz. Optymalna temperatura dla rozwoju tych mikroorganizmów to $15-20^{\circ} \mathrm{C}$. Gatunki roślin spotykane dotychczas jedynie w parkach i ogrodach botanicznych w porach ścian budynku znalazły bardzo podatny grunt do wzrostu i rozwoju. Okazało się, że płaszczyzna przerośnięta plątaniną organizmów jest świetnym izolatorem - pozwala na utrzymanie stałej temperatury w budynku. Zielone organizmy zużywają znaczne ilości dwutlenku węgla, wzbogacają powietrze w tlen, a także w przypadku niektórych gatunków uzupełniają dietę mieszkańców bloków. Pustostany oczekujące na nowych lokatorów stają się w tym okresie wspólną przestrzenią mieszkańców budynków. Opuszczone mieszkania przekształcają się w niewielkie ogródki działkowe.

34 Zob. R. Nahirny Subnatura i miasto. Przyroda poza kontrolq, "Kultura - Historia - Globalizacja” 2014 No. 17. York 2009. 
Dzięki tej nieoczekiwanej transformacji osiedla, centrum miasta uzyskało ponad 14 hektarów powierzchni czynnej biologicznie pochłaniającej rocznie około 650 ton dwutlenku węgla. ${ }^{36}$

Pomysł samorzutnej, pozaludzkiej roślinnej rewitalizacji - jako idea pojawia się coraz częściej w obiegu, uzmysławiając alternatywny finał nowoczesnych urbanistycznych utopii, ufundowanych przecież na idei światła, zieleni, przestrzeni. Projekt Kozakiewicza jest oczywiście ironiczną grą z tymi utopiami, dlatego prezentuje scenariusz optymistyczny. To, co nie udało architekturze nowoczesnych osiedli, a więc przekształcenie mieszkańców we wspólnotę, stało się możliwe za sprawą subnatury.

Kolejność problemów - od ludzkiego prawa do przyrody w mieście do prawa przyrody do życia w ludzkim mieście wskazuje na dokonujące się właśnie przesunięcie akcentów, a dzięki temu stanowi wyrazisty symptom wprowadzania środowiskowej równowagi. Prowadzi bowiem do uznania koegzystencji świata ludzkiego i przyrodniczego w przestrzeni miejskiej. Gdyby spojrzeć na współczesny stosunek do „dzikości” zieleni miejskiej z punktu widzenia projektowanej wspólnoty, można w nim zobaczyć kolejny etap jej poszerzenia, a więc uznanie praw samej przyrody do swobodnego rozwoju.

\section{Miasto jako przyroda}

Zarysowana w paru epizodach historia relacji między przyrodą i miastem mogłaby prowadzić do wniosku, że dają się one ująć w poręczne formuły miejskiej kulturonatury czy naturokultury, o których pisała niedawno Ewa Rewers $^{37}$. W teoriach miejskich najczęściej przy takiej okazji sięga się po koncepcję urbanizacji natury, zaproponowaną przez Erika Swyngedouwa i Marię Kaikę ${ }^{38}$ czy miejskiego metabolizmu Mathew Gandy'ego ${ }^{39}$

36 J. Kozakiewicz Natura (do) mieszkania: https://www.youtube.com/watch?v=ifUj7gvM2nY (6.06.2017).

37 E. Rewers Humanistyka wobec koncepcji 'kulturynatury', "Teksty Drugie” 2017 nr 1, s. 163-174. Zob. też: B. Kwaśny Przyroda w mieście: lokalne i globalne geografie w perspektywie historycznej i współczesnej, „Kultura - Historia - Globalizacja” 2014 nr 16. panion to the City, ed. by G. Bridge, S. Watson, Blackwell Publishing, Oxford 2003.

39 M. Gandy O „miejskim metabolizmie" na nowo. Woda, przestrzeń i nowoczesne miasto, w: Miasto-Zdrój. Architektura i programowanie zmysłów, red. J. Kusiak, B. Piątkowska, Fundacja Bęc Zmiana, Warszawa 2013. 
lub relacyjnej ekologii miejskiej rozumianej jako asamblaż miasta, natury, kultury i technologii ${ }^{40}$. Wszystkie te propozycje zbiegają się w gruncie rzeczy we wspólnym rozpoznaniu, że miasto nie odbiega zasadniczo od naturalnych ekosystemów. Może najcelniej ujął to Gernot Böhme:

Poprzez miasto - [...] - człowiek nie stawia się ponad przyrodą, ani też nie zdobywa możliwości wyjścia poza nią; miasto jest raczej pewnym sposobem, w jaki człowiek żyje z przyrodą i w przyrodzie. Miasto jest i pozostaje przyrodą, jakkolwiek jest to przyroda przyswojona i ukształtowana przez człowieka. [...] Miasto rozumie się wówczas jako element przyrody, który tworzą rośliny i budowle i który nieustannie reprodukowany jest przez użytkowanie i pracę człowieka w przymierzu ze spontanicznością przyrody. ${ }^{41}$

Ten rewolucyjny w gruncie rzeczy skok od pojmowania miasta jako przestrzeni kultury do miasta jako przyrody dotyczy jednak sfery konceptualizacji, można bowiem zauważyć, że jest późnym rozpoznaniem sytuacji istniejącej od zawsze. Niemniej oznacza on, przynajmniej w sferze teoretycznej refleksji, radykalne cięcie, ponieważ opozycja miasto - natura (z jej wariacyjną odmianą miasto - wieś) ustanawiały niegdyś podstawowe linie napięcia i porządkowania rzeczywistości. Koniecznie trzeba przy tym zaznaczyć, że wewnętrzne relacje między przyrodą i miastem mogą przybierać formy symbiotyczne lub konfliktowe, urbanizacja natury to zarówno modny w wielkich miastach urban farming, jak i uprzemysłowiona, oparta na nierównościach socjoekonomicznych produkcja rolna na potrzeby wielkich metropolii ${ }^{42}$. Warto mieć to na uwadze, by uniknąć idealizacji.

Ostatnia kwestia to pytanie o rolę sztuki czy kultury w miejskim ekosystemie. Jedną z odpowiedzi może być strategia zaproponowana w ramach interwencji Co jest za murem? - w czasie projektu wykorzystano peryskop, który umożliwił zobaczenie klasztornych ogrodów ukrytych za ogrodzeniami. Wiele z działań artystycznych inicjowanych w miejskich przestrzeniach realizuje właśnie taką strategię peryskopu - stwarza możliwość spojrzenia

K. Miciukiewicz Urbanizacja natury: w stronę relacyjnej ekologii miejskiej „,Przegląd Socjologiczny" $2011 \mathrm{nr} 2 / 3$, s. 167-185. 
na to, co ukryte, zagrodzone, zakopane, niedostrzegane. Tak będzie w przypadku projektu Cecylii Malik 6 rzek, który pokazał alternatywną wodną sieć Krakowa, czy w Widoku na Czechówkę Ludomira Franczaka, który za pomocą oszklonego włazu odsłonił ukrytą rzekę płynącą w podziemiach Lublina.

Druga z możliwych strategii polega na dołączaniu do środowiska przyrodniczego. W tych projektach w odróżnieniu od laboratoryjnego bioartu, artysta nie jest kreatorem nowego życia, ale działa na zasadzie plug in, wtyczki, wpięcia. Nie kreuje nowych form życia niczym demiurg, ale wpina się w istniejący ekosystem, dzięki czemu sztuka staje się częścią „obiegu materii” w miejskim metabolizmie, jak w przypadku Trafostacji Rajkowskiej. Strategia ta łączy się często z ograniczeniem ludzkiej sprawczości na rzecz aktywności przyrody. Można wreszcie mówić o strategii zielonej utopii - projektowaniu rozwiązań jeszcze niemożliwych, ale wyznaczających kierunki poszukiwań, jak w Architekturze arborealnej Abakanowicz czy Wieżach tlenowych Kozakiewicza.

Najczęściej chyba jednak dochodzi do głosu strategia poszerzania wspólnoty ludzkiej i nie-ludzkiej - jak w działaniach Cecylii Malik czy Karoliny Grzywnowicz. Wspólnota bywa oczywiście pojęciem idealizowanym, z drugiej strony doraźnie zawiązywane i oddolnie inicjowane taktyczne sojusze, kolektywy i kooperatywy od kilkunastu lat skutecznie, choć w mikroskali, przekształcają miasta i zyskują coraz większą sprawczość w oddziaływaniu na polityki miejskie.

Wszystkie natomiast zapowiadają biopolis jako nowy horyzont działań, w których paradygmat eksploatacji przyrody (ciagle mocny i aktywny) jest zastępowany przez kooperację. 


\section{Abstract}

\section{Elżbieta Rybicka}

JAGIELLONIAN UNIVERSITY (CRACOW)

Biopolis: Nature and the City

Rybicka outlines the relationship between the city and nature in two spheres: contemporary art and the history of urban greenery. Symptomatically, both tend to depart from the paradigm of exploiting nature and move towards strategic cooperation between the human and natural environments. This development allows Rybicka to formulate the notion of the biopolis, a postulative concept that integrates the city's material, social and political life with the natural environment.

\section{Keywords}

city, nature, modernity, community, history of parks, contemporary art 